\title{
BIODIVERSITY AND PHYLOGENETIC ANALYSIS OF CULTURABLE BACTERIA INDIGENOUS TO KHEWRA SALT MINE OF PAKISTAN AND THEIR INDUSTRIAL IMPORTANCE
}

\author{
Nasrin Akhtar; Muhammad A. Ghauri*; Aamira Iqbal; Munir A. Anwar; Kalsoom Akhtar \\ Bioprocess Technology Division, National Institute for Biotechnology and Genetic Engineering, Jhang Road, Faisalabad, \\ Pakistan
}

Submitted: April 30, 2007; Returned to authors for corrections: October 16, 2007; Approved: November 15, 2007.

\begin{abstract}
Culturable bacterial biodiversity and industrial importance of the isolates indigenous to Khewra salt mine, Pakistan was assessed. PCR Amplification of $16 \mathrm{~S}$ rDNA of isolates was carried out by using universal primers FD1 and rP1and products were sequenced commercially. These gene sequences were compared with other gene sequences in the GenBank databases to find the closely related sequences. The alignment of these sequences with sequences available from GenBank database was carried out to construct a phylogenetic tree for these bacteria. These genes were deposited to GenBank and accession numbers were obtained. Most of the isolates belonged to different species of genus Bacillus, sharing 92-99\% 16S rDNA identity with the respective type strain. Other isolates had close similarities with Escherichia coli, Staphylococcus arlettae and Staphylococcus gallinarum with $97 \%, 98 \%$ and $99 \%$ 16S rDNA similarity respectively. The abilities of isolates to produce industrial enzymes (amylase, carboxymethylcellulase, xylanase, cellulase and protease) were checked. All isolates were tested against starch, carboxymethylcellulose (CMC), xylane, cellulose, and casein degradation in plate assays. BPT-5, 11,18,19 and 25 indicated the production of copious amounts of carbohydrates and protein degrading enzymes. Based on this study it can be concluded that Khewra salt mine is populated with diverse bacterial groups, which are potential source of industrial enzymes for commercial applications.
\end{abstract}

Key words: Biodiversity, characterization, Highly saline environments, PCR amplification of 16S rDNA, Industrially important enzymes.

\section{INTRODUCTION}

Biodiversity is an attribute of an area and specifically refers to the varieties within and among living organisms, assemblage of the living organisms, biotic communities and biotic processes, whether naturally occurring or modified by humans (2). The vast majority of microbial diversity ( $>95 \%$ ) remains to be discovered $(11,23)$. Very little is known about microbial species and functional diversity, and decisions about the role of microorganisms and their influence on sustainable ecosystems are being made on the basis of very incomplete information (21). Interest in the biodiversity of extreme environments has grown over the past several years for several reasons, including the theory that such extreme conditions were predominant on the young planet Earth. The same line of reasoning underlies the search for life forms from outside our planet. Other reasons for exploring the biodiversity of extreme environments are of more applied nature, including the use of extremozymes in industrial applications (9). Without a thorough knowledge of microbial diversity and ecology, the outcomes of "black box" ecological studies concerned with sustainability are flawed (21). Extreme environments such as acidic, thermophilic, hypersaline, and arid regions, are important 'hot spots' of microbial 'megadiversity'. These are habitats of microorganisms which have the genetic and physiological capacity to survive and grow under these harsh or extreme conditions through which they have evolved while shaping the environment as we know it today $(17,25)$.

*Corresponding Author. Mailing address: Bioprocess Technology Division, National Institute for Biotechnology and Genetic Engineering, P.O.Box \# 577, Jhang Road, Faisalabad, Pakistan. Tel.: +92(0) 41-2651475 - Ext. 252. Fax. +92(0) 41-2651472. E-mail: maghauri@ nibge.org 
Many types of bacterial species have been isolated from various salt environments. Including the Gram-negative halophilic like species of the genera Vibrio, Alteromonas, Acinetobacter, Marinomonas and Pseudomonas (18). Similarly species of the genera Marinococcus, Sporosarcina, Salinococcus and Bacillus have been recovered from saline soils and salterns (5). Previously, a limited study of water samples collected from Khewra salt mine has indicated the presence of bacteria belonging to Halomonas magadiensis and Virgibacillus halodenitrificans (7).

Enzymes such as proteases, amylases, carboxymethylcellulases, cellulases and xylanases are extensively used in the industries for the manufacture of pharmaceuticals, foods, beverages and confectioneries as well as in textile and leather processing, paper industry and waste water treatment (24). The majority of the enzymes used in the industry are microbial in origin because microbial enzymes are relatively more stable than the corresponding enzymes derived from plants and animals (15). Highly saline environments have proven to be a rich source of microorganisms harbouring industrially important enzymes $(4,12)$.

In the present research work we have studied bacterial diversity in the Khewra salt mine. Khewra is the largest salt mine in the world (area wise) and is the second biggest producer of rock salt in the world. The salt range is said to record 600 million years of earth history and the existence of tertiary microfossils is reported (Geological Survey of Pakistan, (http:/ /www. gsp.gov.pk/pakistan). The present study is the first report of its kind that deals with culturable bacterial biodiversity of Khewra salt mine at biochemical and molecular level. Moreover, industrial importance of the isolates with reference to various enzymes and some physico-chemical analyses of samples collected from mine are reported.

\section{MATERIALS AND METHODS}

\section{Sampling}

Four liquids, one slurry and two soil samples were collected in sterile bags/bottles from various sites of Khewra salt mine. These samples were brought to the laboratory under cold conditions and stored at $4^{\circ} \mathrm{C}$ till further use. Soil samples were made into slurries by mixing with sterile distilled water $(50 \%, \mathrm{w} /$ v). A brief description of samples is given in Table 1.

\section{Physico-chemical analysis of the mine samples}

For convenience, physico-chemical analyses of two samples (SL-1 and P1, Table 1) were carried out. Analysis of $\mathrm{Cu}, \mathrm{Cd}, \mathrm{Pb}$, $\mathrm{Fe}, \mathrm{Ni}$, and $\mathrm{Zn}$ was carried out by atomic absorption spectrophotometery (Varian, Australia), while $\mathrm{Na}$ and $\mathrm{K}$, analysis was carried out by using flame photometer (Fp20 SEAC Radium group). Estimation of $\mathrm{Ca}, \mathrm{Mg}, \mathrm{Cl}$, and $\mathrm{SO}_{4}$ ions was carried by various titration methods developed at our laboratory.
Table 1. Description of the samples taken from Khewra salt mine at ambient temperature $\left(25^{\circ} \mathrm{C}\right)$.

\begin{tabular}{cclcc}
\hline Sr. No & $\begin{array}{c}\text { Sample } \\
\text { code }\end{array}$ & \multicolumn{1}{c}{$\begin{array}{c}\text { Sample } \\
\text { site }\end{array}$} & $\begin{array}{c}\text { Nature of } \\
\text { the sample }\end{array}$ & $\mathrm{pH}$ \\
\hline 1 & DS & Drainage & Slurry & 7.5 \\
2 & P1 & Pond 1 & Liquid & 7.1 \\
3 & P3 & Pond 3 & Liquid & 7.3 \\
4 & P3(5) & $\begin{array}{l}\text { Pool 3 near } \\
\text { 5 no pillar }\end{array}$ & Liquid & 7.5 \\
5 & S1 & Soil sample 1 & Soil & 7.8 \\
6 & SL-1 & Soil near water drips & Soil & 7.9 \\
7 & WD1 & $\begin{array}{l}\text { Water drips } \\
\text { from mine roof }\end{array}$ & Liquid & 7.3 \\
& & & \\
\hline
\end{tabular}

\section{Isolation and enrichment of bacteria}

On the basis of high $\mathrm{pH}$ and salt content values of the samples, three culture media were used for the isolation and enrichment of bacteria present in these environmental samples. The composition of these culture media is as follows:

(i) Luria-Bertani $(L B)$ contained $(\mathrm{g} / \mathrm{l})$ : Tryptone 10, Yeast Extract 5, $\mathrm{NaCl}$ 5, and $\mathrm{pH} 7.2$.

(ii) Alkaliphilic Medium (AP) contained (g/l): Yeast Extract 5, Polypeptone 5, $\mathrm{KH}_{2} \mathrm{PO}_{4} 1, \mathrm{MgSO}_{4} 7 \mathrm{H}_{2} \mathrm{O} 0.2$ (solution A), and $\mathrm{Na}_{2} \mathrm{CO}_{3} 10$ (solution $\mathrm{B}$ ), and pH. 9.5

(iii) Halophilic Medium (HP) contained (g/l): Tryptone 10, Beef Extract 10, $\mathrm{NaCl} 65$, and $\mathrm{pH} 7.4$.

For the solid version of all above media $2 \%$ agar was used as gelling agent.

Appropriate volume (5\%) of respective environmental sample was inoculated into respective sterile medium. The flasks were incubated at $25^{\circ} \mathrm{C}$ (initial temperatures of the samples) in a gyratory shaker at $150 \mathrm{rpm}$. Appearance of turbidity was indicative of growth, which was also confirmed by taking optical density reading at $650 \mathrm{~nm}$. Duplicate uninoculated controls for each medium were run parallel to the experimental flasks.

\section{Development of pure cultures}

Samples aliquots and enriched liquid cultures were streaked in duplicate on the respective media plates and incubated at $25^{\circ} \mathrm{C}$. Colonies appeared after 2-4 days of incubation. Representative colonies were inoculated into the respective liquid media and growth was confirmed by the appearance of turbidity and optical density reading at $650 \mathrm{~nm}$.

\section{Preliminary characterization of isolated bacteria}

Colonies on respective media plates were examined using stereomicroscope and their characteristics viz., colour, form, 
elevation, margins etc. were recorded. Cells were examined by using phase contrast microscope to record cell size, morphology, motility and presence or absence of endospores. Isolates were also characterized on the basis of Gram's staining.

\section{Growth studies of enriched bacterial isolates}

Preliminary optimization of growth affecting parameters was carried out at various $\mathrm{pH}$ values (3-11) and temperatures $\left(25^{\circ} \mathrm{C}, 37^{\circ} \mathrm{C}, 45^{\circ} \mathrm{C}\right)$ (data not shown). Mean generation time $\left(\mathrm{t}_{\mathrm{d}}\right)$ and specific growth rate $(\mu)$ were calculated by growing the isolates in their respective media at optimum $\mathrm{pH}$ and temperature. The growth was monitored by taking absorbance at $650 \mathrm{~nm}$ at regular time intervals. A plot of time (hours) against optical density was drawn, and doubling time $\left(t_{d}\right)$ was calculated by noting down the time difference between two points on a straight line (log phase) where optical density increased by two folds with reference to the initial point. Specific growth rate was calculated from the doubling time $\left(\mathrm{t}_{\mathrm{d}}\right)$ using this expression, $\mathrm{t}_{\mathrm{d}}=0.693 / \mu$

\section{Enzyme assays for isolates}

Various enzyme assays were developed/modified at our laboratory by referring documented assays in the literature. Nutrient agar medium (Difco) with $0.5 \%$ substrate was used for amylase, CMCase, xylanase and cellulase enzymes. For Protease assay we used method developed by Montville, 1983 containing $1 \%$ casein, $1 \%$ gelatin and $1.5 \%$ agar. Substrates used for amylase, CMCase, xylanase, cellulase and protease were starch, carboxymethylcellulose, xylane, cellulose and casein respectively.

For starch plates, amylase production was checked with (2\%) iodine solution in the following manner. Iodine solution was poured on the plates and allowed to set the indicator for 5 minutes and then washed with distilled water. Clear zone was observed in blue background around the bacterial growth in amylase positive plates. Cellulose, xylane and carboxymethylcellulose plates were assayed for enzyme activity by staining with Congo red solution $(0.5 \%)$ for 5 minutes. Plates were destained with $1 \mathrm{M} \mathrm{NaCl}$ solution and the presence of enzyme activity was observed from the presence of clear zones around the growth. Protease activity was directly observed as colonies hydrolyzing casein were surrounded by a white halo.

\section{Phylogenetic analysis of isolates}

Genomic DNA was isolated from $50 \mathrm{ml}$ of liquid bacterial culture using the GenomicPrep ${ }^{\mathrm{TM}}$ Cells and Tissue DNA isolation Kit (Amersham Pharmacia Biotech.) and stored at $-20^{\circ} \mathrm{C}$ till further use. Polymerase chain reaction (PCR) amplification of $16 \mathrm{~S}$ ribosomal DNA of isolates was carried out using the following primers and set of conditions (6).

Forward primer (FD1) AGAGTTTGATCCTGGCTCAG

Reverse primer(rP1) ACGG(ACT)TACCTTGTTACGACTT
Each vial contained $50 \mu \mathrm{l}$ of reaction mixture containing $34.75 \mu \mathrm{l}$ nano pure water, $5 \mu \mathrm{l}$ of $1 \mathrm{X}$ PCR buffer, $6 \mu \mathrm{l}$ of $25 \mathrm{mM}$ $\mathrm{MgCl}_{2}, 0.25 \mu \mathrm{l}$ of $1 \mathrm{U}$ Taq polymerase, $1 \mu \mathrm{l}$ of $2 \mathrm{mM}$ dNTPs, $1 \mu \mathrm{l}$ of each primer (FD1, rP1, $100 \mathrm{pmol} / \mu \mathrm{l})$ and $1 \mu \mathrm{l}$ template DNA, respectively. The reaction mixture was heated for 2 minutes at $96^{\circ} \mathrm{C}$ and then amplification was carried out in 30 cycles. Each cycle was comprised of 30 seconds at $95^{\circ} \mathrm{C}, 40$ seconds at $55^{\circ} \mathrm{C}$ and 2 minutes at $72^{\circ} \mathrm{C}$. The final extension was for 10 minutes at $72^{\circ} \mathrm{C}$. The PCR product was purified using Rapid PCR purification system (Marligen Bioscience, USA).

Amplified 16S rDNA fragment of about $1,500 \mathrm{bp}$ size obtained from each isolate $(750 \mathrm{ng} / \mu \mathrm{l})$ was partially sequenced commercially (GeneLink ${ }^{\mathrm{TM}}$, Hawthorne, New York). The gene sequences were compared with others in the GenBank databases using the NCBI BLAST (www.ncbi.nlm.nih.gov). Gene sequences of 16S rDNA of selected organisms were obtained from GenBank and aligned with gene sequence of our isolates using CLUSTALX software. The aligned sequences were used to construct a distance matrix (13), after the generation of 100 bootstrap sets, that was subsequently used to construct a phylogenetic tree by neighborjoining method (19), using Treecon for windows (22).

\section{Nucleotide sequence accession numbers}

Accession numbers of the partial 16S rDNA sequences for isolates were obtained by depositing partial sequences with GenBank of National Center for Biotechnology Information (www.ncbi.nlm.nih.gov). The accession numbers (in parentheses) of the other 16S rDNA sequences used in the phylogenetic tree development are as follows: Escherichia coli (Z83205); Bacillus sphaericus strain PLC-5 (AY161044); Bacillus fumarioli (AJ250057); Bacillus amyloliquefaciens strain ATCC 15841 (AY055226); Bacillus cereus (AJ577275); Bacillus licheniformis strain GXN151 (AY291582); Staphylococcus arlettae (AB009933); Bacillus licheniformis strain KL-176 (AY030335); Bacillus licheniformis strain KL182 (AF387514); Staphylococcus gallinarum (AB092801); Bacillus licheniformis strain Mo1 (AF372616); Bacillus pumilus strain KL-052 (AY030327); Halomonas Halmophila Strain ATCC 19717 (AJ306889); Bacillus clausii DSM 8716 (X76440); Bacillus halodenitrificans (AB021186); Bacillus clarkii DSM 8720 (X76444); Bacillus halodurans (AB021187); Bacillus alcalophilus DSM 485 T (X76436); Bacillus carboniphilus (AB021182); Arthrobacter keyseri (AF256196); Halomonas magadiensis Lake Nakuru isolate 19N1 (X92149); Arthrobacter ureafaciens (X80744); Alloiococcus otitis (AF193887).

\section{RESULTS}

\section{Chemical analysis of mine samples}

For convenience, two representative mine samples (with highest and lowest salt content) were analysed for detailed studies of physico-chemical parameters (Table 2). 
Table 2. Physico-chemical characteristics of mine samples including sample $\mathrm{pH}$, conductivity $(\mathrm{mS} / \mathrm{ml})$ and concentration of selected ions and metals (in $\mathrm{mg}^{-1}$ ).

\begin{tabular}{ccc}
\hline Parameter & SL-1 & P1 \\
\hline $\mathrm{pH}$ & 7.9 & 7.1 \\
Conductivity & 95 & 108 \\
$\mathrm{Na}$ & 13667 & 53068 \\
$\mathrm{~K}$ & 3733 & 1264 \\
$\mathrm{Cu}$ & 0.669 & 0.67 \\
$\mathrm{Cd}$ & 0.377 & 0.658 \\
$\mathrm{~Pb}$ & 4.140 & 2.632 \\
$\mathrm{Fe}$ & 6.803 & 3.280 \\
$\mathrm{Ni}$ & 7.736 & 4.552 \\
$\mathrm{Zn}$ & 0.721 & 0.721 \\
$\mathrm{Ca}$ & 180 & 3200 \\
$\mathrm{Mg}$ & 540 & 972 \\
$\mathrm{C}$ & 450000 & 176000 \\
$\mathrm{SO}_{4}$ & 2927 & 1108 \\
$\mathrm{CO}_{3}$ & $\mathrm{Nil}$ & $\mathrm{Nil}$ \\
\hline
\end{tabular}

SL-1: Soil near water drips coming from the roof of the Khewra mine P1: Pond 1 in the Khewra mine.

\section{Colony and cell morphologies of isolates}

Fifteen isolates were selected for further studies on the basis of the colony colour and bacterial morphology keeping in mind that there should be at least one representative for each sample (Table 3). Colonial pigmentation of the isolates included orange, yellow, red, cream coloured, and white. These colonies were irregular and circular in form while few were punctiform. Colony elevations were raised, flat, umbonate and pulvinate. Most of colonies had entire and undulate margins and few of them had lobate margins (Table 3). Different isolates displayed different cell sizes and morphologies when viewed under the phase contrast microscope. They were coccus shaped, ovoid and rod shaped (Table 3). Some of the isolates were indicated to contain terminal endospores. Some rod shaped isolates tended to form small ( $4-5$ cells) or long chains ( $8-12$ cells). Most of the isolates were motile in nature and were Gram, s negative.

\section{Growth studies of enriched bacterial isolates}

Optimization studies were carried out at various temperatures and $37^{\circ} \mathrm{C}$ was found to be the optimum temperature for all the isolates, so the growth studies were carried out at $37^{\circ} \mathrm{C}$. Optimum $\mathrm{pH}$ value used for respective medium has been indicated in the materials and methods section. The mean generation time $\left(\mathrm{t}_{\mathrm{d}}\right)$ ranged from 1-4.3 hours and specific growth rate $(\mu)$ ranged from $0.16-0.69 \mathrm{~h}^{-1}$ amongst various isolates (Table 3 ).

Table 3. Some characteristics of different isolates enriched from Khewra salt mine samples.

\begin{tabular}{|c|c|c|c|c|c|c|c|c|c|c|}
\hline \multirow[t]{2}{*}{$\begin{array}{l}\text { Sample } \\
\text { code }\end{array}$} & \multirow[t]{2}{*}{$\begin{array}{c}\text { Media* } \\
\text { used }\end{array}$} & \multirow[t]{2}{*}{$\begin{array}{l}\text { Isolate } \\
\text { code }\end{array}$} & \multicolumn{4}{|c|}{$\begin{array}{c}\text { Colony } \\
\text { morphology }\end{array}$} & \multirow{2}{*}{$\begin{array}{l}\text { Cell shape } \\
\text { and size } \\
(\mu \mathrm{m})\end{array}$} & \multirow[t]{2}{*}{$\begin{array}{l}\text { Endos- } \\
\text { pores }\end{array}$} & \multirow{2}{*}{$\begin{array}{c}\text { Mean } \\
\text { generation } \\
\text { time } t_{d} \\
(h)\end{array}$} & \multirow{2}{*}{$\begin{array}{c}\text { Specific } \\
\text { growth } \\
\text { rate } \mu \\
\left(\mathrm{h}^{-1}\right)\end{array}$} \\
\hline & & & Colour & Form & Elevation & Margins & & & & \\
\hline \multirow[t]{3}{*}{ DS } & LB & BPT-12 & Orange & Irregular & Raised & Undulate & Rods, 1-1.5 & + & 2.1 & 0.33 \\
\hline & HP & ВРТ-15 & Cream & Punctiform & Flat & Entire & Rods-coccus, $1-1.5$ & - & 2.3 & 0.30 \\
\hline & $\mathrm{AP}$ & ВРT-23 & Yellow & Circular & Raised & Entire & Rods, 2-3 & - & 3.0 & 0.23 \\
\hline P1 & LB & ВРТ-7 & Yellow & Irregular & Raised & Entire & Rods, 1-1.5 & + & 1.2 & 0.58 \\
\hline \multirow[t]{3}{*}{ P3 } & LB & ВРТ-3 & Cream & Circular & Flat & Entire & Rods, $1-2$ & - & 3.3 & 0.21 \\
\hline & LB & ВРТ-6 & Red & Irregular & Umbonate & Undulate & Rods, $1-1.5$ & + & 1.0 & 0.69 \\
\hline & AP & BPT-18 & Orange & Irregular & Umbonate & Undulate & Rods, $1-1.5$ & - & 2.4 & 0.29 \\
\hline P3 (5) & AP & ВРТ-20 & Yellow & Irregular & Raised & Lobate & Rods, 2-2.5 & + & 1.5 & 0.45 \\
\hline SL-1 & LB & BPT-5 & White & Irregular & Flat & Undulate & Rods, $1-1.5$ & + & 1.5 & 0.47 \\
\hline \multirow[t]{2}{*}{ WD1 } & LB & ВРТ-8 & White & Circular & Raised & Entire & Coccus, $0.5-1$ & - & 2.3 & 0.30 \\
\hline & LB & ВРТ-11 & Red & Circular & Pulvinate & Entire & Ovoid, 0.5-1 & - & 2.4 & 0.28 \\
\hline
\end{tabular}

*LB-Luria Bertani, HP-Halophilic Medium, AP-Alkaliphilic Medium. 


\section{Enzymes assays}

Enzyme assays were carried by using substrates based solid media plates as described in materials and methods (Section 2). Out of fifteen isolates, five gave non significant positive results while ten other were significantly positive for such assays, indicating copious amounts of enzyme production (Table 5).

\section{PCR amplification of the 16S rDNA}

DNA samples were PCR amplified using conditions earlier developed by Ghauri et al. (2003). A product of about $1,500 \mathrm{bp}$ was obtained in case of all isolates. Nucleotide blast search of partial sequences of the 16S rDNA for various isolates showed that most of the isolates had variable \% identity with Bacillus sp. (92-99\%). Isolates BPT2, BPT-8 and BPT-15 had 97\%, 98\% and 99\% homology with Escherichia coli, Staphylococcus arlettae and Staphylococcus gallinarum respectively (Table 4).

\section{Acquisition of accession number for 16S rDNA sequences and construction of phylogenetic tree}

Accession numbers of the partial 16S rDNA sequences for the isolates in this study are as follows: BPT-2 (AY430288), BPT-3 (AY430289), BPT-4 (AY430290), BPT-5 (AY430292), BPT-6 (AY430293), BPT-7 (AY430294), BPT-8 (AY430291), BPT-11 (AY430302), BPT-12 (AY430295), BPT-15 (AY430296), BPT-18 (AY430297), BPT19(AY430298), BPT-20 (AY430299), BPT-23 (AY430300), BPT25 (AY430301). A phylogenetic tree was developed by
Table 5. Different enzyme assays for isolates from Khewra salt mine.

\begin{tabular}{|c|c|c|c|c|c|}
\hline $\begin{array}{l}\text { Isolate } \\
\text { Code }\end{array}$ & Amylase & CMCase & Xylanase & Cellulase & Protease \\
\hline BPT-2 & - & - & - & - & - \\
\hline BPT-3 & - & - & - & - & slightly + \\
\hline ВРТ-4 & - & - & - & - & slightly + \\
\hline BPT-5 & + & + & + & + & + \\
\hline BPT-6 & + & + & - & + & + \\
\hline BPT-7 & + & + & - & - & + \\
\hline BPT-8 & + & - & - & - & + \\
\hline BPT-11 & + & + & + & + & + \\
\hline BPT-12 & + & + & - & - & - \\
\hline BPT-15 & slightly + & - & - & - & - \\
\hline BPT-18 & + & + & + & + & - \\
\hline BPT-19 & + & + & + & + & - \\
\hline BPT-20 & - & - & - & - & + \\
\hline BPT-23 & - & H & - & - & + \\
\hline BPT-25 & + & + & + & + & + \\
\hline htly + & $\begin{array}{l}\text { No clear zon } \\
\text { Clear zone a } \\
\text { Clear zone fo } \\
\text { Larger clear }\end{array}$ & $\begin{array}{l}\text { e formation } \\
\text { very small } \\
\text { rmation } \\
\text { zone forma }\end{array}$ & tion than + & & \\
\hline
\end{tabular}

aligning 16S rDNA sequences of different bacteria (given in material method section) and sequences of the isolates from this study (Fig. 1)

Table 4. Closest known bacteria to various isolates from Khewra salt mine based on 16S rDNA sequence.

\begin{tabular}{clc}
\hline Isolate & \multicolumn{1}{c}{ Nearest relative } & Identity (\%) \\
\hline BPT-2 (AY430288) & Escherichia coli (Z83205) & 97 \\
BPT-3(AY430289) & Bacillus fumarioli (AJ250057) & 92 \\
BPT-4(AY430290) & Bacillus sphaericus (AY161044) & 98 \\
BPT-5(AY430292) & Bacillus amyloliquefaciens (AY055226) & 98 \\
BPT-6(AY430293) & Bacillus cereus (AJ577275) & 98 \\
BPT-7(AY430294) & Bacillus licheniformis strain GXN151 (AY291582) & 98 \\
BPT-8(AY430291) & Staphylococcus arlettae (AB009933) & 98 \\
BPT-11(AY430302) & Bacillus licheniformis strain KL-176 (AY030335) & 97 \\
BPT-12(AY430295) & Bacillus licheniformis strain KL-182(AF387514) & 99 \\
BPT-15(AY430296) & Staphylococcus gallinarum (AB092801) & 99 \\
BPT-18(AY430297) & Bacillus licheniformis strain KL-176 (AY030335) & 99 \\
BPT-19(AY430298) & Bacillus licheniformis strain KL-176 (AY030335) & 93 \\
BPT-20(AY430299) & Bacillus licheniformis strain KL-176 (AY030335) & 98 \\
BPT-23 (AY430300) & Bacillus licheniformis strain GXN151 (AY291582) & 99 \\
BPT-25(AY430301) & Bacillus pumilus (AY030327) & 99 \\
\hline
\end{tabular}

The numbers in parentheses are the database accession numbers for the given sequence. 


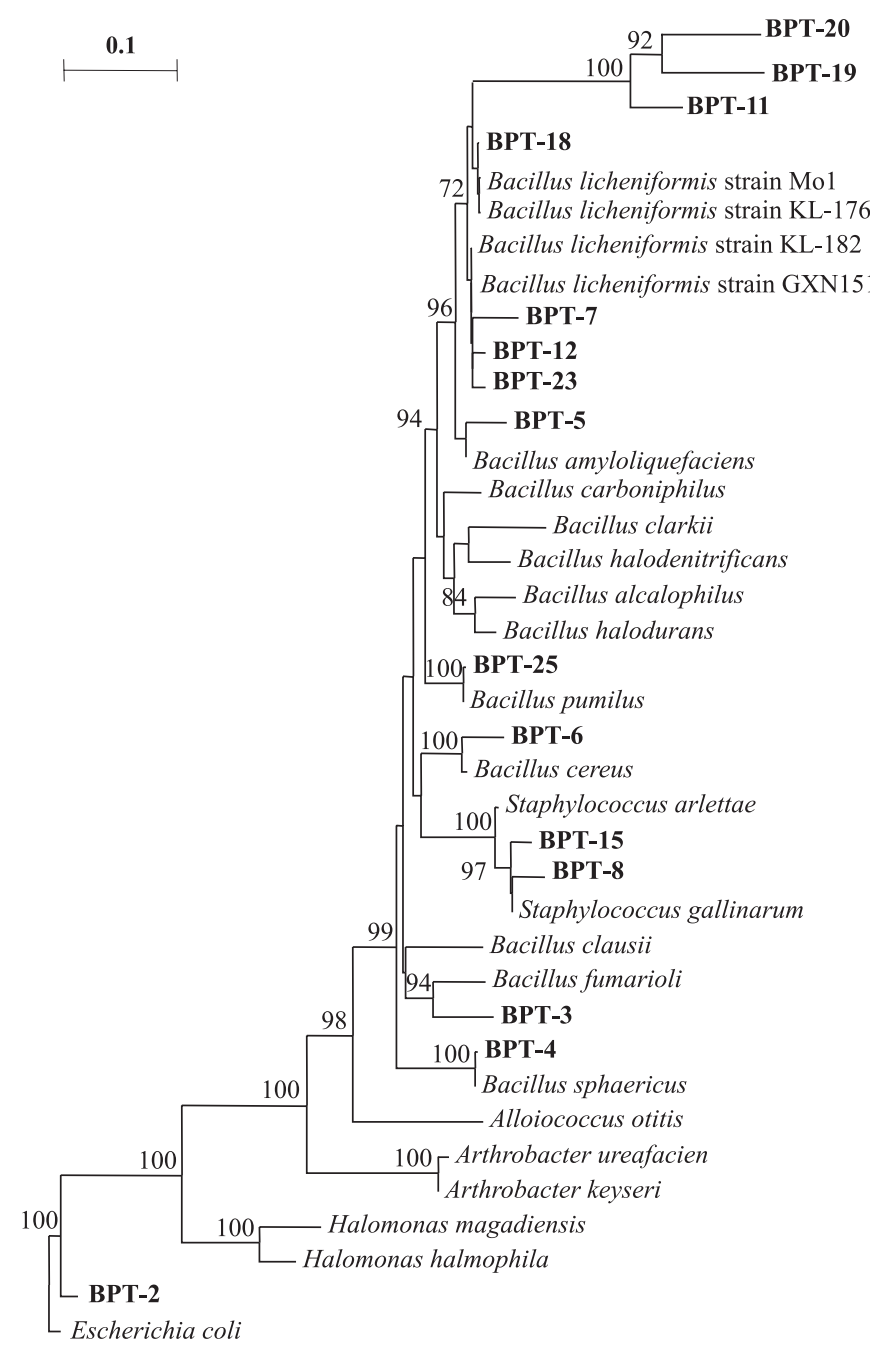

Figure 1. The inferred relationship, based on partial 16S rDNA sequence, of the Khewra salt mine isolates, isolated in this study (in bold) to other bacteria. The tree was rooted with Escherichia coli. Scale bar represents the number of inferred nucleotide substitution per site. Bootstrap values (100 replicates) are shown at the nodes.

\section{DISCUSSION}

In the present study isolation and preliminary characterization of bacteria indigenous to Khewra salt mine, Pakistan coupled with a molecular approach, in which case PCR amplification of 16S rDNA sequence based bacterial identification was attempted to study the culturable bacterial diversity in the Khewra salt mine. Moreover, the ability of the isolates to produce industrially important enzymes was also checked.

Samples were taken from the $6^{\text {th }}$ floor because it was the only functional floor while others were abandoned and we were allowed to collect samples only from $6^{\text {th }}$ floor. The chemistry of the samples collected from various parts of the mine was highly diverse and was in accordance to other studies e.g., Grant $e t$ al., 1998 (8). The values of $\mathrm{Na}, \mathrm{K}, \mathrm{Ca}, \mathrm{Mg}, \mathrm{Cl}$, and $\mathrm{SO}_{4}$ ions were found comparable to the values investigated in diverse salt environments (8).

Preliminary characterization studies depicted great deal of diversity in terms of colonial morphologies and microscopic studies. Similarly, bacterial diversity was also evident when we estimated mean generation time $\left(t_{d}\right)$ and specific growth rate $(\mu)$ of various isolates. It can be envisaged that microorganisms have a very crucial role in the cycling of various nutrient components in a closed system like Khewra mine. Therefore, their growth rates may impart crucial influence in the cycling of such nutrients. Calculating growth patterns and rates in laboratory may enable to envisage growth limitations, which may be prevailing in the natural environment. Thus giving some critical insights of some ecological pressures under which these microorganisms were thriving and their possible ecological role.

The results presented here further extend the preliminary observations, and indicate considerable phylogenetic diversity within a closed ecological environment. The majority of media employed were rich in organic carbon and may support a wide range of microorganisms present in such environments. All the Bacillus and Staphylococcus species are Gram's negative in our study, which is deviant from the results quoted by other workers. However, Duckworth et al. (1996) (3) have reported that normal Gram's staining procedures may prove unsatisfactory in some cases. We assume that the same phenomenon might have been operative in the case of our isolates.

Isolate BPT-2 was related to $E$. coli, with which it shared $97 \%$ similarity in its $16 \mathrm{~S}$ rDNA sequence, however morphological characteristics of this isolate were relatively distinct from typical E. coli rendering it to be a different strain of the same species. E. coli generally forms large, circular and pink colonies on MacConkey plate and are Gram's negative rods but in our case BPT-2 formed yellow, circular colonies on LB media plates and were rod-coccus shaped. The doubling time $\left(\mathrm{t}_{\mathrm{d}}\right)$ for $E$. coli is normally 20 minutes but for BPT- 2 it was about 2 hours. It means that BPT-2 is a different isolate from $E$. coli. Use of different solid and liquid media for studying the characteristics of this isolate might have contributed to variable characteristics as compared to reported in the literature. Conclusively, though BPT-2 isolate resembled very closely to $E$. coli on the basis $16 \mathrm{~S}$ rDNA sequence but on the basis of morphology and biochemical characteristics it is quite distinct from E. coli so tentatively rendering it a different strain of the same species.

On molecular basis, most of the isolates belonged to the Bacillus genus, indicating that bacteria belonging to this group were more prevalent in salt containing environments compared 
to other microbial groups that may be found under such environments. However bacterial diversity was more evident on the basis of presence/absence of endospores in case of our isolates related to Bacillus species. Out of seven $B$. licheniformis strains (BPT-7, 11, 12, 18, 19, 20 and 23) only three (BPT-7, 12, and 20) formed endospores (Table 3). Moreover, out of four strains (BPT-11, 18, 19, 20) having same accession number only BPT-20 indicated terminal endospores when viewed under the microscope. Similarly, amongst two other strains of the $B$. licheniformis (BPT-7 and BPT-23) only BPT-7 indicated the presence of terminal endospores.

Isolate BPT-3 matched with B. fumarioli and shared 92\% relatedness for its $16 \mathrm{~S} \mathrm{rDNA}$ as well as it was quite similar to this species in cultural characteristics. Isolates BPT-7, 11, 12, $18,19,20$ and 23 matched with B. licheniformis with $16 \mathrm{~S}$ rDNA similarity of $98,97,99,99,93,98$, and $99 \%$ respectively. Isolate BPT-5 matched with B. amyloliquefaciens with $98 \% 16 \mathrm{~S}$ rDNA identity. While BPT- 6 and BPT-25 matched with $B$. cereus with 16S rDNA identity of $98 \%$ and B. pumilus with $16 \mathrm{~S}$ rDNA similarity of $98 \%$ respectively, thus making this genus highly diverse at biochemical as well as at molecular level. Highly diverse nature of Bacillus genus found in this study is in accordance with the observations made by other workers $(1,10)$. Due to the ubiquity and capability to survive under adverse conditions, heterotrophic Bacillus strains cannot be considered species of certain specific habitats (1). It is therefore not surprising that a large number of the isolates recovered in the present study belonged to the same bacterial group.

Isolates BPT-8 and BPT-15 were related to $S$. arlettae (98\%16S rDNA similarity) and S. gallinarum (99\% 16S rDNA similarity) respectively. Their morphology is some how similar to other reported Stapylococcus species, however such bacteria have not been reported to be naturally occurring in high salt environments. Staphylococci have been isolated sporadically from a wide variety of environmental sources such as soil, beach sand, seawater, fresh water, dust and air in various inhabited areas (14). It is highly likely that such groups might have migrated to these environments from surroundings during the course of time.

These bacteria have indicated production of copious amount of enzymes, could be exploited for commercial applications (12). Most of the isolates described in this study belonged to different species of the Genus Bacillus. It has been documented that Bacillus species are attractive industrial organisms for a variety of reasons, including their high growth rates leading to short fermentation cycle time and their ability to secrete proteins in extracellular medium (20). In the present study B. amyloliquefaciens (BPT-5), B. cereus (BPT-6), $B$. licheniformis (BPT-11, 18,19) and B. pumilus (BPT-25) were found to be efficient producers of industrially important enzymes with tremendous potential for commercial exploitation.
This is the first report investigating the microbiology of the Khewra salt mine, which has been proven to be an important ecological nich for industrially important microorganisms. Culturing microbes and molecular analysis give us an edge to have more and more cultured microorganisms with their taxonomic status from any sort of such environment. Especially with the view that microbial studies pertaining to culturing of microorganisms from extreme environments is extremely sporadic. Though, traditionally extraction of environmental DNA may enhance the extant of biodiversity contained in these samples, but at the same hand gives us less opportunity to know the exact profile of cultural characteristics of the microorganisms of any such environment. Therefore the strategy to culture microorganisms from any environmental sample and then designing a methodology that delineates biodiversity increases the prospect of having microbial resource in hand which can be further used for other purposes at a later stage.

\section{RESUMO}

\section{Biodiversidade e análise filogenética de bactérias cultiváveis indígenas da mina de sal Khewra, Paquistão e sua importância industrial}

Avaliou-se a biodiversidade e a importância industrial de bactérias indígenas da mina de sal Khewra, Paquistão. Efetuouse a amplificação do $16 \mathrm{~S}$ rDNA dos isolados por PCR empregandose os iniciadores universais FD1 e rP1, e os produtos foram seqüenciados comercialmente. Essas seqüências de genes foram comparadas com outras seqüências disponíveis no GenBank a fim de encontrar seqüências relacionadas, construindo-se uma árvore filogenética para essas bactérias. Os genes foram depositados no GenBank obtendo-se os números de acesso. A maioria dos isolados pertenceu a diferentes espécies do gênero Bacillus, apresentando 92-99\% de identidade de 16S rDNA com a respectiva cepa de referencia. Outros isolados apresentaram alta similaridade com Escherichia coli, Staphylococcus arlettae e Staphylococcus gallinarum, com 97\%, $98 \%$ e $99 \%$ de similaridade de16S rDNA, respectivamente. A capacidade dos isolados produzirem enzimas industriais (amilase, carboximetilcelulase, xilanase, celulase e protease) foi verificada. Todos os isolados foram testados em placas quanto a degradação de amido, carboximetilcelulose, xilana, celulose e caseína. Os isolados BPT-5, 11, 18, 19 e 25 produziram grandes quantidades de enzimas degradadoras de carboidratos e proteínas. Conclui-se que a mina de Sal Khewra apresenta diferentes grupos de bactérias, que são fontes potenciais de enzimas industriais de aplicação comercial.

Palavras-chave: biodiversidade, caracterização, ambiente de alta salinidade, amplificação de $16 \mathrm{~S}$ rDNA por PCR, enzimas industriais. 


\section{REFERENCES}

1. Claus, D.; Berkeley, R.C.W. (1986). Genus Bacillus Cohn 1872. In: Sneath, P.H.A. (ed). Bergey's Manual of Systematic Bacteriology. Williams \& Wilkins, Baltimore, p.1105-39.

2. DeLong, D.C. (1996). Defining biodiversity. Wildlife Soc. Bull., 24, 38-749.

3. Duckworth, A.W.; Grant, W.D.; Jones, B.E.; Steenbergen, R.V. (1996). Phylogenetic diversity of soda lake alkaliphiles. FEMS Microbiol. Ecol., 19, 181-191.

4. Eveleigh, D.E. (1981). The microbial production of industrial chemicals. Sci. American., 245, 155-178.

5. Farrow, J.A.E.; Ash, C.; Wallbanks, S.; Collins, M.D. (1992). Phylogenetic analysis of the genera Planococcus, Marinococcus and Sporosarcina and their relationship to the genus Bacillus. FEMS Microbiol. Lett., 93, 167-172.

6. Ghauri, M.A.; Khalid, A.M.; Grant. S.; Heaphy, S.; Grant, W.D. (2003). Phylogenetic analysis of different isolates of sulfobacillus spp. recovered from uranium rich environments and recovery of genes using integron specific primers. Extremophiles, 7, 341-345.

7. Ghauri, M.A.; Khalid, A.M.; Grant, S.; Grant, W.D.; Heaphy, S. (2006). Phylogenetic analysis of bacterial isolates from man-made high-pH, high-salt environments and identification of gene-cassette-associated ORFs. Curr. Microbiol., 52, 487-492.

8. Grant, W.D.; Gemmel, R.T.; Mcgenity, T.J. (1998). Halophiles. In: Horikoshi, K.; Grant, W.D. (eds). Extremophiles. Wiley-Liss, New York, p.93-132.

9. Hallberg, K.B.; Johnson, D.B. (2001). Biodiversity of acidophilic Prokaryotes. In: Laskin, A.; Bennett, J.W.; Gadd, G. (eds). Advances in Applied Microbiology. Academic Press, San Diego, p.37-84.

10. Holt, J.G.; Krieg, N.R.; Sneath, P.H.A.; Staley, J.T.; Williams, S.T. (1994). Endospore forming Gram-positive rods and cocci. In: Hensyl, W.R. (ed). Bergey's Manual of Determinative Bacteriology. William and Wilkins, Baltimore USA, p.559.

11. Hugenholtz, P.; Pace, N.R. (1996). Identifying microbial diversity in the natural environment: a molecular phylogenetic approach. TIBTECH. 14, 190-197.

12. Horikoshi, K. (1999). Extracellular Enzymes. In: Horikoshi, K. (ed). Alkaliphiles. Harwood Academic Publishers, Japan, p.147-285.
13. Jukes, T.H.; Cantor, C.R. (1969). Evolution of protein molecules. In: Munro, H.N. (ed). Mammalian protein metabolism. Academic, New York, p.21-132.

14. Kloos, W.E.; Schleifer, K.; Gotz, F. (1992). The Genus Staphylococcus. In: Balows, A.; Truper, H.G.; Dworkin, M.; Harder, W.; Schleifer, K.H. (eds). The Prokaryotes. Springer-Verlag, New York, p.1369-1420.

15. Mohapatra, B.R.; Bapuji, M.; Sree, A. (2003). Production of industrial enzymes (Amylase, Carboxymethylcellulase and Protease) by bacteria isolated from marine sedentary organisms. Acta. Biotechnol., 23(1), 75-84

16. Montville, T.J. (1983). Dual-substrate plate diffusion assay for proteases. Appl. Envir. Microbiol., 45(1), 200-204.

17. Olsen, G.J.; Woese, C.R.; Overbeek, R.C. (1994). The winds of (evolutionary) change: breathing new life into microbiology. $J$. Bacteriol., 176, 1-6.

18. Prado, B.; Del Moral, A.; Quesada, A.; Rios, R.; Monteoliva-Sanchez, M.; Campos, V. Ramos-Cormenzana, A. (1991). Numerical taxonomy of moderately gram negative rods isolated from solar de Atacama Chile. Syst. Appl. Microbiol., 14, 275-281.

19. Saitou, N.; Nei, M. (1987). The neighbour-joining method: a new method for reconstruction phylogenetic trees. Mol. Biol. Evolu., 4, 406-425.

20. Schallmey, M.; Singh, A.; Ward, O.P. (2004). Developments in the use of Bacillus species for industrial production. Canad. J. Microbiol., 50, $1-17$.

21. Sly, L.I. (1998). Australian Microbial Resources. Microbiol. Australia, 19(1), 27-35

22. Van de peer, Y.; De Wachter, R. (1993). TREECON: a software package for the construction and drawing of evolutionary trees. Comput. Appl. Biosci., 9, 177-182.

23. Ward, D.M.; Weller, R.; Bateson, M.M. (1990). 16S rRNA sequences reveal numerous uncultured microorganisms in a natural community. Nature (London), 345, 63-65.

24. Wiseman, A. (1985). Handbook of Enzyme Biotechnology. New York, Ellis Horwood Ltd., P. 274-379.

25. Woese, C.R. (1987). Bacterial evolution. Microbiol. Rev., 51, 221271. 